Jurnal IImu Hukum - http://repository.unpas.ac.id/14165/

\title{
ANALISIS YURIDIS TERHADAP LAPORAN PAJAK TERUTANG ATAS TRANSAKSI E-COMMERCE DALAM RANGKA MEWUJUDKAN KEPASTIAN HUKUM
}

\author{
Abdul Rahman Tibahary \\ NPM. 148040016
}

\begin{abstract}
ABSTRAK
Teknologi informasi mempunyai pengaruh yang sangat besar terhadap perekonomian dunia. Sehubungan dengan perkembangan teknologi tersebut, khususnya telekomunikasi, multimedia dan teknologi informasi (telematika) pada akhirnya dapat mengubah tatanan organisasi dan hubungan sosial masyarakat. Dalam penelitian ini mempertanyakan laporan pajak terutang atas transaksi E-Commerce yang tentu saja tidak akan terlepas dari peraturan perundang-undangan mengatur tentang pajak atas transaksi E-Commerce, laporan terhadap pajak terutang atas transaksi E-Commerce dan kepastian hukum dalam pelaporan pajak atas transaksi E-Commerce.

Metode penelitian yang digunakan dalam penelitian ini adalah deskriptis analitis yaitu suatu metode penelitian yang dimaksudkan untuk menggambarkan mengenai fakta-fakta berupa data dengan bahan hukum primer dalam bentuk peraturan perundang-undangan yang terkait dan bahan hukum sekunder (doktrin, pendapat para pakar hukum terkemuka) serta bahan hukum tersier. Sedangkan pendekatan dalam penelitian ini menggunakan pendekatan kualitatif yang berusaha mengkombinasikan pendekatan normatif dan empiris. Melalui penelitian ini diharapkan memperoleh gambaran secara komprehensif mengenai laporan pajak terutang atas transaksi E-Commerce.

Hasil penelitian pajak atas transaksi E-Commerce sama dengan transaksi biasa sesuai dengan penjelasan pada Pasal 11 ayat (1) Undang-Undang Pajak Pertambahan Nilai diatur bahwa "Pemungutan Pajak Pertambahan Nilai dan Pajak Penjualan atas Barang Mewah menganut prinsip akrual, artinya terutangnya pajak terjadi pada saat penyerahan Barang Kena Pajak atau pada saat penyerahan Jasa Kena Pajak, meskipun pembayaran atas penyerahan tersebut belum diterima atau belum sepenuhnya diterima, atau pada saat impor Barang Kena Pajak. Saat terutangnya pajak untuk transaksi yang dilakukan melalui E-Commerce tunduk pada ayat ini. Terkait dengan laporan pajak terutang yang dihasilkan dari transaksi atas E-Commerce ini dapat dilakukan dengan pendekatan Harmonisasi dan konvergensi agar kepastian dalam pelaporan pajak atas transaksi elektronik dapat terlaksana dengan sebaik-baiknya.
\end{abstract}

Kata kunci: Transaksi E-Commerce, Pajak, Pajak Terutang. 


\section{ANALISIS YURIDIS TERHADAP LAPORAN PAJAK TERUTANG ATAS TRANSAKSI E-COMMERCE DALAM RANGKA MEWUJUDKAN KEPASTIAN HUKUM}

\section{PENDAHULUAN}

Dunia usaha di zaman sekarang dapat dilakukan baik secara langsung atau menggunakan media komputer yang saling terhubung yang disebut dengan Internet. Karena didukung oleh sebuah jaringan internet sehingga para pelaku bisnis dapat menjual dan menawarkan jasa melalui online. Internet merupakan jaringan komputer terbesar di dunia pada saat ini digunakan oleh berjuta-juta orang yang tersebar di dunia.

Hal tersebut ditandai dengan lahirnya penggunaan internet sebagai media perdagangan oleh perusahaan ataupun konsumen dalam melakukan transaksi yang menyebabkan setiap individu memiliki hak dan kemampuan untuk berhubungan dengan individu lain tanpa ada batasan. Perkembangan yang pesat dalam bidang teknologi di berbagai sektor juga membawa dampak kepada perkembangan di dunia usaha. Hal ini bisa disimak dari kegiatan usaha melalui $E$ Commerce, sebagai hasil dari kemajuan di sektor komunikasi dan teknologi informasi. Kemajuan yang pesat di dunia usaha tidak selalu diikuti dengan tingkat yang sama dalam bidang regulasi. Ecommerce merupakan metode perdagangan modern yang tidak mempertemukan penjual dan pembeli maka untuk terjadinya suatu kesepakatan sulit untuk diketahui dengan jelas kapan kesepakatan antara kedua belah pihak itu terjadi. ${ }^{1}$

Ada banyak definisi untuk E-Commerce, tapi yang pasti E-Commerce merujuk pada semua bentuk transaksi komersial yang menyangkut organisasi dan individu yang didasarkan pada proses dan transmisi data yang digitalisasikan, termasuk teks, suara dan gambar. Termasuk juga pengaruh bahwa pertukaran informasi komersial secara elektronik yang mungkin terjadi antara institusi pendukungnya dan aktivitas komersial pemerintah. Ini termasuk antara lain manajemen organisasi, negosiasi dan kontrak komersial, legal dan kerangka regulasi, penyusunan perjanjian keuangan, dan pajak satu sama lain. Electronic Commerce (Perniagaan Elektronik), sebagai bagian dari Electronic Business (bisnis yang dilakukan dengan menggunakan electronic transmission), oleh para ahli dan pelaku bisnis dicoba dirumuskan definisinya. Secara umum E-Commerce dapat didefinisikan sebagai segala bentuk transaksi perdagangan atau perniagaan barang dan jasa (trade of goods and service) dengan menggunakan media elektronik. Jelas, selain dari yang telah disebutkan di atas, bahwa kegiatan perniagaan tersebut merupakan bagian dari kegiatan bisnis.

\footnotetext{
${ }^{1}$ Lia Sautunnida, Jual Beli Melalui Internet, Sinar Harapan, Bandung, 2008, hlm. 34.
}

$$
2
$$


Berbeda dengan transaksi perdagangan biasa pada umumnya, transaksi E-Commerce memiliki beberapa karakteristik yang sangat khusus sehingga mengakibatkan implikasi pajak yang agak rumit dari kegiatan tersebut. Hal ini terjadi karena transaksi elektronik antara e-merchant (pihak yang menawarkan barang atau jasa melalui internet) dengan e-customer, (pihak yang membeli barang atau jasa melalui internet) yang terjadi di dunia maya atau di internet pada umumnya berlangsung secara paperless transaction, sedangkan dokumen yang digunakan dalam transaksi tersebut bukanlah paper document, melainkan dokumen elektronik (digital document).

Saat ini, pajak merupakan kontributor terbesar dari Anggaran Pendapatan dan Belanja Negara (APBN) yang berarti perannya sangat besar bagi kelangsungan pembangunan bangsa ini. ${ }^{2}$ Pajak merupakan sumber pendapatan negara yang sangat penting bagi penyelenggaraan pemerintahan dan pelaksanaan pembangunan nasional. Sehingga pemerintah menempatkan kewajiban perpajakan sebagai salah satu perwujudan kenegaraan yang merupakan sarana dalam pembiayaan negara dalam pembangunan nasional guna tercapainya tujuan negara.

Terkait pajak, transaksi perdagangan secara elektronik dikenakan pajak sesuai peraturan perundang-undangan yang berlaku, Pelaku Usaha yang menawarkan secara elektronik kepada Konsumen Indonesia wajib tunduk pada ketentuan perpajakan Indonesia karena dianggap memenuhi kehadiran secara fisik dan melakukan kegiatan usaha secara tetap di Indonesia.

Meski pasar E-Commerce berkembang pesat di Indonesia namun baru segelintir pelaku $E$ Commerce yang sudah memiliki Nomor Pokok Wajib Pajak (NPWP). Menurut data yang diperoleh dari Direktorat Jenderal Pajak ada 1.600 (seribu enam ratus) sampling (pelaku ECommerce) yang dicoba, dari jumlah itu ada 600 (enam ratus) yang belum teridentifikasikan dan 1.000 (seribu) sudah teridentifikasikan. ${ }^{3}$ Dari 1.000 (seribu) pelaku usaha baru 620 (enam ratus dua puluh) yang sudah memiliki Nomor Pokok Wajib Pajak (NPWP). ${ }^{4}$ Dari yang sudah memiliki Nomor Pokok Wajib Pajak (NPWP) itu sebagian besar sudah melapor tapi tidak diketahui dilaporkannya itu sudah sesuai fakta yang terjadi pada saat bertransaksi.

Menurut data yang ada di Direktorat Jenderal Pajak, nilai pasar dari suatu transaksi $E$ -

Commerce di Indonesia sudah mencapai Rp 96.000.000.000.000.00 (sembilan puluh enam

${ }^{2}$ Achmad Tjahjono dan Muhammad Fakhri Husein, Perpajakan ed. 3, cet.ke 1, Akademi Manajemen Perusahaan YKPN, Yogyakarta, 2005, hlm. 2.

${ }^{3}$ Nufransa Wira Sakti, Kepala Subdit Manajemen Transformasi dalam Seminar Perpajakan "Pemenuhan Kewajiban Perpajakan Bagi Pelaku e- Commerce Di Indonesia" yang diadakan oleh Direkorat Jenderal (Ditjen) Pajak di Jakarta, 27 Agustus 2014. Makalah, hlm. 5.

${ }^{4}$ Ibid, hlm. 5. 
triliun rupiah) pada tahun 2015 dan akan meningkat sampai Rp 288.000.000.000.000.00 (dua ratus delapan puluh delapan triliun rupiah) di tahun 2016 ini. Sejak tahun 2012, Direktorat Jenderal Pajak sudah melakukan kajian tentang E-Commerce. Pertama terhadap aspek-aspek perpajakan yang ada, sehingga mendapatkan apa yang harus dilakukan terhadap perkembangan dunia E-Commerce ini. Kedua membentuk tim di Direktorat Jenderal Pajak yang terdiri dari tim untuk memutuskan peraturan-peraturan atau tatacara aspek perpajakannya, kemudian tentang pengelolaan, penggalian potensi pajaknya. ${ }^{5}$

Direktorat Jenderal Pajak mengeluarkan Surat Edaran-62/PJ/2013 dikeluarkan pada bulan desember 2013 (tentang Penegasan Ketentuan Perpajakan atas Transaksi E-Commerce) yang diharapkan agar bisa menjadi penegasan bahwa ketentuan perpajakan terkait dengan transaksi atas E-Commerce itu sama ketentuannya mulai dari mendaftar, menghitung, membayar, melapor, itu juga berlaku bagi setiap pelaku usaha yang melakukan kegiatan $e$ Commerce ini.

Diharapkan nantinya timbul kesadaran bagi pelaku E-Commerce ini bahwa sesungguhnya tidak ada perbedaan antara perpajakan yang dilakukan dengan sistem perdagangan konvensional maupun dengan sistem melalui E-Commerce.

\section{IDENTIFIKASI MASALAH}

Berdasarkan latar belakang di atas, peneliti mengidentifikasikan permasalahannya sebagai berikut:

1. Bagaimana peraturan perundang-undangan mengatur tentang pajak atas transaksi $E$ Commerce?

2. Bagaimana laporan terhadap pajak terutang atas transaksi E-Commerce dalam rangka kepastian hukum?

3. Bagaimana kepastian hukum dalam pelaporan pajak atas transaksi E-Commerce?

\section{METODE PENELITIAN}

Spesifikasi penelitian yang digunakan dalam melakukan penelitian ini adalah deskriptif analitis, yaitu suatu metode penelitian yang dimaksudkan untuk menggambarkan mengenai faktafakta berupa data dengan bahan hukum primer dalam bentuk peraturan Perundang-undangan yang terkait dan bahan hukum sekunder berupa doktrin-doktrin atau pendapat para pakar hukum mengenai hukum perlindungan konsumen serta bahan tersier yaitu bibliografi, kamus besar bahasa

\footnotetext{
${ }^{5}$ Ibid, hlm. 7.
} 
Indonesia, dan kamus hukum. Melalui penelitian ini diharapkan memperoleh gambaran secara komprehensif mengenai laporan pajak terutang atas transaksi E-Commerce.

Metode pendekatan yang digunakan dalam penelitian adalah metode pendekatan yuridis normatif, yaitu menetapkan standar atau norma tertentu terhadap suatu fenomena dengan mengkaji data skunder.

Berkenaan dengan pendekatan yuridis normatif yang digunakan, maka penelitian yang dilakukan melalui dua tahap yaitu studi kepustakaan dan penelitian lapangan yang hanya bersifat penunjang. Penelitian kepustakaan (library research) adalah suatu penelitian yang dilakukan untuk mempelajari, mengkaji dan menganalisis data sekunder yang berupa bahan hukum primer, sekunder dan tersier. Bahan hukum primer sebagai bahan hukum yang diperoleh langsung dari berbagai peraturan perundang-undangan mulai dari UUD 1945 hingga ketentuan hukum yang bersifat teknis yang berkaitan erat dengan perlindungan konsumen.

Studi kepustakaan juga meliputi bahan-bahan hukum sekunder berupa literatur, karya ilmiah, makalah, hasil penelitian, loka karya, bahan kuliah yang berkaitan dengan materi yang diteliti. Untuk melengkapi dan menjelaskan materi bahan-bahan hukum primer dan sekunder, digunakan bahan tersier. Penelitian lapangan (field research) ini dimaksudkan untuk mendapat data primer, tetapi diperlukan hanya untuk menunjang dan melengkapi data sekunder dalam data kepustakaan. Bahan hukum primer sebagai bahan hukum yang diperoleh langsung dari berbagai peraturan perundang-undangan yang terkait dengan perpajakan.

Adapun teknik pengumpulan data yang digunakan dalam penelitian ini yaitu: a) Studi dokumen, b) Observasi, dan c) Wawancara. Sesuai dengan metode pendekatan yang diterapkan, maka data yang diperoleh data penelitian ini dianalisis secara yuridis kualitatif, yaitu mengkualifikasikan dan mengklasifikasikan masalah-masalah secara sistematis kemudian dianalisis secara kualitatif dengan tidak menggunakan rumus-rumus matematis dan angka-angka statistik.

\section{PEMBAHASAN}

A. Peraturan Perundang-undangan Yang Mengatur Tentang Pajak Atas Transaksi ECommerce

Pajak atas transaksi E-Commerce sesuai dengan SE-62/PJ/2013 telah mempertegas bahwa tidak ada pajak baru dalam transaksi E-Commerce sehingga tidak ada perbedaan dalam penerapan peraturan perundang-undangan perpajakan antara transaksi E-Commerce ataupun 
konvensional. Oleh karena itu bagi penjual atau pembeli dapat dikenakan pajak sesuai ketentuan perundang-undangan perpajakan yang sudah ada. ${ }^{6}$

Pajak atas transaksi E-Commerce bertujuan untuk menerapkan keadilan bagi semua wajib pajak baik konvensional maupun E-Commerce. Karena pada dasarnya kewajiban wajib pajak pelaku bisnis konvensional atau E-Commerce tidak berbeda.

Kegagalan dalam memungut pajak dari transaksi E-Commerce akan mengakibatkan tidak dilaksanakannya prinsip keadilan dan kepastian dalam penegakan hukum, mengakibatkan ketidakseimbangan dalam persaingan antara pengusaha karena beban pajak yang tidak merata di antara wajib pajak tersebut, serta penerimaan negara dari pajak yang tidak maksimal.

Pajak atas transaksi E-Commerce sama dengan transaksi biasa sesuai dengan penjelasan pada Pasal 11 ayat (1) Undang-Undang Pajak Pertambahan Nilai diatur bahwa "Pemungutan Pajak Pertambahan Nilai dan Pajak Penjualan atas Barang Mewah menganut prinsip akrual, artinya terutangnya pajak terjadi pada saat penyerahan Barang Kena Pajak atau pada saat penyerahan Jasa Kena Pajak, meskipun pembayaran atas penyerahan tersebut belum diterima atau belum sepenuhnya diterima, atau pada saat impor Barang Kena Pajak. Saat terutangnya pajak untuk transaksi yang dilakukan melalui E-Commerce tunduk pada ayat ini.

Sebagaimana dijelaskan di dalam penegasan peraturan perpajakan SE-62/PJ/2013 atas E-Commerce, Perkembangan teknologi informasi dan komunikasi telah menyebabkan transformasi model dan strategi bisnis yang perlu ditegaskan aspek perpajakannya. Pada prinsipnya, transaksi perdagangan barang dan/atau jasa melalui sistem elektronik, yang selanjutnya disebut E-Commerce sama dengan transaksi perdagangan barang dan/atau jasa lainnya, tetapi berbeda dalam hal cara atau alat yang digunakan. Oleh karena itu, tidak ada perbedaan perlakuan perpajakan antara transaksi E-Commerce dan transaksi perdagangan barang dan/atau jasa lainnya. ${ }^{7}$

Dalam Surat Edaran Direktorat Jenderal Pajak ini diberikan penegasan mengenai aspek Ketentuan Umum dan Tata Cara Perpajakan, Pajak Penghasilan, dan Pajak Pertambahan Nilai dan Pajak Penjualan atas Barang Mewah atas transaksi E-Commerce.

Dasar-dasar hukumnya adalah sebagai berikut: ${ }^{8}$ Undang-Undang Nomor 6 tahun 1983 tentang Ketentuan Umum dan Tata Cara Perpajakan sebagaimana telah beberapa kali diubah

\footnotetext{
Buyung Muniriyanto, Menelusur Pajak Atas Transaksi E-Commerce, http://www.pajak.go.id/content/article/menelusur-pajak-atas-transaksi-e-commerce, Kamis 23 April 2015, diakses pada tanggal 7 September 2016 - 13:32.

${ }^{7}$ Nufransa Wira Sakti, Op. Cit, hlm. 179.

${ }^{8}$ Ibid, hlm. 180.
} 
terakhir dengan Undang-Undang Nomor 16 tahun 2009 dan peraturan pelaksanaannya, Undang-Undang Nomor 7 tahun 1983 tentang Pajak Penghasilan sebagaimana telah beberapa kali diubah terakhir dengan Undang-Undang Nomor 36 tahun 2008 dan peraturan pelaksanaannya, Undang-Undang Nomor 8 tahun 1983 tentang Pajak Pertambahan Nilai Barang dan Jasa dan Pajak Penjualan Atas Barang Mewah sebagaimana telah beberapa kali diubah terakhir dengan Undang-Undang Nomor 42 tahun 2009 dan peraturan pelaksanaannya.

Subjek Pajak akan dikenakan pajak apabila menerima atau memperoleh penghasilan. Dasar hukum Pajak Penghasilan adalah Undang-Undang Nomor 7 Tahun 1984 tentang Pajak Penghasilan (PPh) sebagaimana telah diubah dengan Undang-Undang Nomor 36 tahun 2008. Undang-Undang ini mengatur pengenaan pajak terhadap subjek pajak berkenaan dengan penghasilan yang diterima atau diperolehnya dalam tahun pajak. ${ }^{9}$

Sebagaimana yang telah dijelaskan, terdapat tiga asas pemungutan pajak yaitu, ${ }^{10}$ Asas Domisili atau Asas Tempat Tinggal, Dimana negara berhak mengenakan pajak atas seluruh penghasilan wajib pajak yang bertempat tinggal di wilayahnya, baik penghasilan yang berasal dari dalam maupun luar negri, dan asas ini berlaku untuk wajib pajak dalam negeri. Asas Sumber, Dimana negara berhak mengenakan pajak atas penghasilan yang bersumber di wilayahnya tanpa memperhatikan tempat tinggal wajib pajak. Asas Kebangsaan, Dimana pengenaan pajak dihubungkan dengan kebangsaan suatu negara.

Negara-negara Organisation for Economic Co-operation and Development (OECD) telah sepakat bahwa pemungutan pajak penghasilan atas transaksi E-Commerce yang memiliki Bentuk Usaha Tetap (BUT) akan menggunakan asas sumber, jika tidak memiliki Bentuk Usaha Tetap maka akan digunakan asas domisili.

Bentuk Usaha Tetap menurut Pasal 2 ayat (5) Undang-Undang Pajak Penghasilan yaitu Bentuk Usaha Tetap adalah bentuk usaha yang dipergunakan oleh orang pribadi yang tidak bertempat tinggal di Indonesia, orang pribadi yang berada di Indonesia tidak lebih dari 183 (seratus delapan puluh tiga) hari dalam jangka waktu 12 (dua belas) bulan, dan badan yang tidak didirikan dan tidak bertempat kedudukan di Indonesia untuk menjalankan usaha atau melakukan kegiatan di Indonesia, yang dapat berupa, Tempat kedudukan manajemen, Cabang perusahaan, Kantor perwakilan, Gedung kantor, Pabrik, Bengkel, Gudang, Ruang untuk promosi dan penjualan, Pertambangan dan penggalian sumber alam, Wilayah kerja

\footnotetext{
${ }^{9}$ Mardiasmo, Op. Cit, hlm. 135.

${ }^{10}$ Ibid.
} 
pertambangan minyak dan gas bumi, Perikanan, peternakan, pertanian, perkebunan, atau kehutanan.

Proyek konstruksi, instalasi, atau proyek perakitan, Pemberian jasa dalam bentuk apapun oleh pegawai atau orang lain, sepanjang dilakukan lebih dari 60 (enam puluh) hari dalam jangka waktu 12 (dua belas) bulan, Orang atau badan yang bertindak selaku agen yang kedudukannya tidak bebas, Agen atau pegawai dari perusahaan asuransi yang tidak didirikan dan tidak bertempat kedudukan di Indonesia yang menerima premi asuransi atau menanggung resiko di Indonesia, Komputer, agen elektronik atau peralatan otomatis yang dimiliki, disewa, atau digunakan oleh penyelenggara transaksi elektronik untuk menjalankan kegiatan usaha melalui internet.

Implikasi pajak untuk E-Commerce akan timbul apabila penyewa atas space di Internet Service Provider atau penyedia jasa Internet adalah perusahaan yang berdomisili di luar negeri. ${ }^{11}$ Bahwa semua transaksi yang terkait dengan persiapan untuk mengoperasikan website, terhadap server dimiliki oleh wajib pajak luar negeri, perlakuannya akan sama dengan yang telah dijelaskan di atas. Misalnya salah satu penyewa website, yang merupakan wajib pajak luar negeri, menggunakan website tersebut untuk menyimpan informasi tertentu, yang kemudian ditawarkan ke pihak ketiga, sehingga pihak ketiga menjadi pelanggannya, dan pelanggan tersebut membayar iuran untuk mengakses informasi yang dimaksud, akan dimasukkan dalam kategori royalty sesuai dengan penjelasan Pasal 4 ayat (1) huruf (h) Undang-Undang Pajak Penghasilan. Sehingga apabila pelanggannya wajib pajak Indonesia, maka penyewa website harus dipotong Pajak Penghasilan Pasal 26. ${ }^{12}$

Pajak Pertambahan Nilai (PPN) adalah pajak yang dikenakan terhadap penyerahan atas impor Barang Kena Pajak (BKP) atau Jasa Kena Pajak (JKP) yang dilakukan oleh Pengusaha Kena Pajak, dan dapat dikenakan berkali-kali setiap ada pertambahan nilai dan dapat dikreditkan. Dasar hukum Pajak Pertambahan Nilai adalah Undang-Undang Nomor 8 Tahun 1983 tentang Pajak Pertambahan Nilai dan atau Penjualan atas Barang Mewah sebagaimana telah diubah dengan Undang-Undang Nomor 42 Tahun 2009.

Seperti yang tertera dalam Pasal 11 ayat (1) Undang-Undang Nomor 8 Tahun 1983 sebagaimana yang telah diubah dalam Undang-Undang Nomor 42 Tahun 2009, terutangnya pajak terjadi pada saat, Penyerahan Barang Kena Pajak, Impor Barang Kena Pajak, Penyerahan

11 Agung Budilaksono, Bagaimana Perlakuan Pajak dari Transaksi E-Commerce di Indonesia, http://www.bppk.depkeu.go.id, Widyaiswara Pusdiklat Bea dan Cukai, 2011. Di akses 8 September 2016 11:33.

12 Ibid. 
Jasa Kena Pajak, Pemanfaatan Barang Kena Pajak Tidak Berwujud dari Luar Daerah Pabean, Pemanfaatan Jasa Kena Pajak dari Luar Daerah Pabean, Ekspor Barang Kena Pajak Berwujud, Ekspor Barang Kena Pajak Tidak Berwujud, Ekspor Jasa Kena Pajak.

Pajak Pertambahan Nilai menurut Pasal 12 Undang-Undang Nomor 42 Tahun 2009 yaitu, Pengusaha Kena Pajak terutang pajak di tempat tinggal atau tempat kedudukan dan tempat kegiatan usaha dilakukan atau tempat lain yang ditetapkan oleh Direktorat Jenderal Pajak, Atas pemberitahuan secara tertulis dari Pengusaha Kena Pajak, Direktorat Jenderal Pajak dapat menetapkan satu tempat atau lebih sebagai tempat pajak terutang, Dalam hal impor, terutangnya pajak terjadi di tempat Barang Kena Pajak dimasukkan.

Pemungutannya dilakukan oleh Direktorat Jenderal Bea dan Cukai, Orang pribadi atau badan yang memanfaatkan Barang Kena Pajak Tidak Berwujud dan/atau Jasa Kena Pajak yang berasal dari luar daerah Pabean di dalam daerah Pabean, terutang pajak di tempat tinggal atau tempat kedudukan dan/atau tempat kegiatan usaha.

Hal tersebut senada dengan Organisation for Economic Co-operation and Development (OECD) yang merekomendasikan tempat terutang dari Pajak Pertambahan Nilai dan Pajak Penjualan atas Barang Mewah, yaitu dimana konsumsi atas barang/jasa terjadi, dalam Pasal 1 dari empat model perpajakan untuk transaksi E-Commerce yaitu perpajakan atas perdagangan lintas batas harus di bawah jurisdiksi dimana konsumsi dilakukan. ${ }^{13}$

Prinsip-prinsip perpajakan atas E-Commerce adalah ${ }^{14}$ Neutrality, Perpajakan seharusnya menjadi netral dan adil dalam membedakan antara bentuk transaksi E-Commerce dengan bentuk transaksi konvensional. Keputusan bisnis seharusnya dimotivasi oleh keadaan ekonomi dibandingkan dengan pertimbangan pajak. Wajib pajak dalam situasi dan transaksi yang sama seharusnya menjadi subjek yang sama pula dalam level perpajakan. Efficiency, Compliance cost untuk Wajib Pajak dan Administrative cost bagi pejabat pajak seharusnya dapat diminimalkan sejauh mungkin.

Certainty and Simplicity, peraturan perpajakan harus jelas dan mudah untuk dimengerti, jadi Wajib Pajak dapat mengantisipasi konsekuensi-konsekuensi pajak sebelum terjadi transaksi, termasuk mengetahui kapan, dimana dan bagaimana pajaknya terhitung. Effectiveness and Fairness, Perpajakan harus menghasilkan jumlah yang tepat dari pajak itu sendiri, sehingga

13 Susan Teltscher, Tariffs, Taxes and Electronic Commerce: Revenue Implications For Developing Countries. Policy Issues in International Trade and Commodities Study Series No.5, http://citeseerx.ist.psu.edu. Diakses 8 September 2016 19:14.

14 Torbjorn Fredriksson, E-Commerce and Development Key Trends and Issue, http://www.wto.org, 2013, di akses 8 September 2016 19:46. 
harus dapat meminimalisir potensi penghindaran pajak (tax avoidance) dan penggelapan pajak (tax evasion) dengan tetap mengukur resiko yang dapat terjadi. Flexibility, Sistem perpajakan seharusnya bersifat fleksibel dan dinamis untuk memastikan mereka sejalan dengan teknologi dan perkembangan komersial. Jadi tidak ada untuk membebaskan E-Commerce dari pajak. Besarnya pajak akan dikenakan pada transaksi dengan media elektronik adalah sebanyak yang dapat dikenakan pajak dengan media fisik.

Dengan adanya prinsip-prinsip perpajakan ini, maka hakikat berlakunya aturan-aturan hukum ini tidak terlepas dari hukum yang berlaku karena penetapan penguasa negara, dan hukum yang tidak tergantung dari pandangan manusia tentang baik buruknya, hukum yang asli. ${ }^{15}$ Bahwa segala kejadian di alam ini diperintah dan dikemudikan oleh suatu undangundang abadi yang menjadi dasar kekuasaan dari semua peraturan-peraturan lainnya.

Terdapat 4 macam golongan hukum (rechtscategorien), yaitu lex aeterna, lex naturalis, lex divina, hukum positif. ${ }^{16}$ Lex Aeterna (Hukum Abadi), yaitu rasio Tuhan sendiri yang mengatur segala hal yang ada sesuai dengan tujuan dan sifatnya, karena itu merupakan sumber dari segala hukum, Lex Divina (Hukum Ke-Tuhanan), yaitu sebagian kecil dari rasio Tuhan yang diwahyukan kepada manusia, Lex Naturalis (Hukum Alam), yaitu bagian dari Lex Divina yng dapat ditangkap oleh rasio manusia atau merupakan penjelmaan dari Lex Aeterna di dalam rasio manusia berkat rasio manusia, dan Hukum Positif, yaitu hukum yang berlaku sungguhsungguh di dalam masyarakat.

\section{B. Laporan Pajak Terutang Atas Transaksi E-Commerce Dalam Rangka Kepastian Hukum}

Hukum merupakan sebuah sistem norma yang menekankan aspek "seharusnya" atau das sollen, dengan menyertakan beberapa peraturan tentang apa yang harus dilakukan. Normanorma merupakan produk dan aksi manusia yang deliberatif. Undang-undang yang berisi aturan-aturan yang bersifat umum menjadi pedoman bagi individu bertingkah laku dalam bermasyarakat, baik dalam hubungan dengan sesama individu maupun dalam hubungannya dengan masyarakat. Aturan-aturan itu menjadi batasan bagi masyarakat dalam membebani atau melakukan tindakan terhadap individu. Adanya aturan itu dan pelaksanaan aturan tersebut menimbulkan kepastian hukum. ${ }^{17}$

\footnotetext{
${ }^{15}$ CST Kansil, Pengantar Ilmu Hukum dan Tata Hukum Indonesia, Balai Pustaka, Jakarta, 1989, hlm. 59.

${ }^{16}$ Titik Triwulan, Pengantar Ilmu Hukum, Prestasi Pustakarya, Jakarta, 2006, hlm. 147-148.

${ }^{17}$ Peter Mahmud Marzuki, Pengantar Ilmu Hukum, Kencana, Jakarta, 2008, hlm. 158.
} 
Selain kepastian hukum, hukum pajak juga memiliki berbagai fungsi yang berdasarkan kepada azas-azas yang bertujuan utama menyejahterakan penduduknya. Fungsi yang pertama dalam hukum pajak yaitu sebagai acuan dalam menciptakan sistem pemungutan pajak yang harus memenuhi syarat kepastian, efisien, dan sederhana sejelas-jelasnya dalam undang-undang hukum pajak itu sendiri, juga sebagai sumber yang menerangkan tentang mana dan siapa subjek maupun objek yang perlu dan tidak perlu dijadikan sumber pemungutan pajak yang berfungsi untuk meningkatkan potensi pajak di negara ini. Adapun laporan pajak terutang ini berfungsi sebagai acuan dalam pembagian beban pajak kepada rakyat yang didasarkan pada kepentingan masing-masing orang.

Tujuan hukum yang mendekati realistis adalah kepastian hukum. Sekiranya dapat dikemukakan bahwa "summum ius, summa injuria, summa lex, summa crux" yang artinya adalah hukum yang keras dapat melukai, kecuali keadilan yang dapat menolongnya, dengan demikian kendatipun keadilan bukan merupakan tujuan hukum satu-satunya akan tetapi tujuan hukum yang paling substantif adalah keadilan.

Menurut Pasal 1 ayat (10) Undang-Undang Nomor 16 Tahun 2009 disebutkan bahwa pajak yang terutang adalah pajak yang harus dibayar pada suatu saat, dalam Masa Pajak, dalam Tahun Pajak, atau dalam Bagian Tahun Pajak sesuai dengan ketentuan peraturan perundangundangan perpajakan. Mengetahui penentuan saat terutang pajak Pengusaha Kena Pajak dalam melaksanakan kewajiban membayar pajaknya adalah sangat penting. Tanpa mengetahui saat pajak terutang, tidak mungkin dapat ditentukan kapan Pengusaha Kena Pajak harus memenuhi kewajiban pelunasan utang pajaknya.

Penentuan saat pajak terutang sangat erat kaitannya dengan penentuan saat timbulnya utang pajak. Pemungutan Pajak Pertambahan Nilai dan Pajak Penjualan atas Barang Mewah menganut prinsip akrual, artinya terutangnya pajak terjadi pada saat penyerahan Barang Kena Pajak atau Jasa Kena Pajak, meskipun pembayaran atas penyerahan tersebut belum diterima atau belum sepenuhnya diterima pada saat impor Barang Kena Pajak.

Saat terutangnya pajak untuk transaksi yang dilakukan melalui E-Commerce tunduk pada ketentuan ini: ${ }^{18}$ Penyerahan Barang Kena Pajak, Impor Barang Kena Pajak, Penyerahan Jasa Kena Pajak, Pemanfaatan Barang Kena Pajak tidak berwujud dari luar Daerah Pabean. Dalam hal orang pribadi atau badan memanfaatkan Barang Kena Pajak tidak berwujud dari luar Daerah Pabean di dalam Daerah Pabean atau memanfaatkan Jasa Kena Pajak dari luar Daerah

${ }^{18}$ Gustian Djuanda Irwansyah Lubis, Pelaporan Pajak Pertambahan Nilai Dan Pajak Penjualan Atas Barang Mewah, PT Gramedia Pustaka Utama, Jakarta, 2011, hlm. 52. 
Pabean di dalam Daerah Pabean, terutangnya pajak terjadi pada saat orang pribadi atau badan tersebut mulai memanfaatkan Barang Kena Pajak tidak berwujud atau Jasa Kena Pajak tersebut di dalam Daerah Pabean.

Hal itu dihubungkan dengan kenyataan bahwa yang menyerahkan Barang Kena Pajak tidak berwujud atau Jasa Kena Pajak tersebut di luar Daerah Pabean sehingga tidak dapat dikukuhkan sebagai Pengusaha Kena Pajak. Karena itu, saat pajak terutang tidak lagi dikaitkan dengan saat penyerahan, tetapi dikaitkan dengan saat pemanfaatan, Pemanfaatan Jasa Kena Pajak dari luar Daerah Pabean, Ekspor Barang Kena Pajak berwujud, Ekspor Barang Kena Pajak tidak berwujud, Ekspor Jasa Kena Pajak.

Dalam hal pembayaran diterima sebelum penyerahan Barang Kena Pajak atau sebelum penyerahan Jasa Kena Pajak atau dalam hal pembayaran dilakukan sebelum dimulainya pemanfaatan Barang Kena Pajak tidak berwujud atau Jasa Kena Pajak dari luar Daerah Pabean, saat terutangnya pajak adalah pada saat pembayaran.

Pelaporan pajak dapat disampaikan ke Kantor Pelayanan Pajak (KPP) atau Kantor Pelayanan, Penyuluhan dan Konsultasi Pajak (KP2KP) di mana wajib pajak terdaftar. Surat Pemberitahuan (SPT) dapat dibedakan menjadi Surat Pemberitahuan Masa dan Surat Pemberitahuan Tahunan. ${ }^{19}$

Surat Pemberitahuan Masa adalah Surat Pemberitahuan yang digunakan untuk melakukan pelaporan atas pembayaran pajak pada masa tertentu (bulanan). Ada 9 (sembilan) jenis Surat Pemberitahuan Masa, meliputi Surat Pemberitahuan Masa untuk melaporkan pembayaran bulanan. Pajak Penghasilan Pasal 21, Pajak Penghasilan Pasal 22, Pajak Penghasilan Pasal 23, Pajak Penghasilan Pasal 25, Pajak Penghasilan Pasal 26, Pajak Penghasilan Pasal 4 ayat (2), Pajak Penghasilan Pasal 15, Pajak Pertambahan Nilai dan Pajak Penjualan atas Barang Mewah, Pemungutan Pajak Pertambahan Nilai.

Sedangkan yang dimaksud dengan Surat Pemberitahuan Tahunan adalah Surat Pemberitahuan yang digunakan untuk pelaporan tahunan. Ada 2 (dua) jenis Surat Pemberitahuan Tahunan, yaitu Surat Pemberitahuan Tahunan Pajak Penghasilan Wajib Pajak Badan, dan Surat Pemberitahuan Tahunan Wajib Pajak orang pribadi.

Saat ini khusus untuk Surat Pemberitahuan Masa Pajak Pertambahan Nilai sudah dapat disampaikan secara elektronik melalui aplikasi e-Filling. Penyampaian Surat Pemberitahuan

19 Kenali Aturan Dalam Pelaporan Pajak, pajak.go.id, Minggu 11 November 2012 13:02, di akses 10 September 2016 22:57. 
Tahunan Pajak Penghasilan juga dapat dilakukan secara online melalui aplikasi $e$-SPT. Dasar Pengenaan Pajak (DPP) adalah sebagai berikut. ${ }^{20}$

Harga jual, adalah nilai berupa uang, termasuk semua biaya yang diminta atau seharusnya diminta oleh penjual karena penyerahan Barang Kena Pajak, tidak termasuk Pajak Pertambahan Nilai yang dipungut menurut Undang-Undang Pajak Pertambahan Nilai dan potongan harga yang dicantumkan dalam Faktur Pajak.

Penggantian, adalah nilai berupa uang, termasuk semua biaya yang diminta atau seharusnya diminta oleh pengusaha karena penyerahan Jasa Kena Pajak, ekspor Jasa Kena Pajak, atau ekspor Barang Kena Pajak Tidak Berwujud, tetapi tidak termasuk Pajak Pertambahan Nilai yang dipungut menurut Undang-Undang Pajak Pertambahan Nilai dan potongan harga yang dicantumkan dalam Faktur Pajak atau nilai berupa uang yang dibayar atau seharusnya dibayar oleh Penerima Jasa karena pemanfaatan Jasa Kena Pajak dan/atau oleh penerima manfaat Barang Kena Pajak Tidak Berwujud karena pemanfaatan Barang Kena Pajak Tidak Berwujud dari luar Daerah Pabean di dalam Daerah Pabean.

Nilai Impor, adalah nilai berupa uang yang menjadi dasar perhitungan bea masuk ditambah pungutan berdasarkan ketentuan dalam peraturan perundang-undangan yang mengatur mengenai kepabean dan cukai untuk impor Barang Kena Pajak, tidak termasuk Pajak Pertambahan Nilai dan Pajak Penjualan atas Barang Mewah yang dipungut menurut UndangUndang Pajak Pertambahan Nilai. Nilai Ekspor, adalah nilai berupa uang, termasuk biaya yang diminta atau seharusnya diminta oleh eksportir.

Penerapan Dasar Pengenaan Pajak diatur dalam berbagai peraturan pelaksanaan undangundang sebagai berikut. Untuk penyerahan atau penjualan Barang Kena Pajak, yang menjadi Dasar Pengenaan Pajak adalah jumlah harga jual, Untuk penyerahan Jasa Kena Pajak, yang menjadi Dasar Pengenaan Pajak adalah penggantian, Untuk impor yang menjadi Dasar Pengenaan Pajak adalah nilai impor, Untuk ekspor yang menjadi Dasar Pengenaan Pajak adalah nilai ekspor.

Batas Waktu Pembayaran Pajak diatur di dalam PPh Pasal 21, Dilunasi paling lambat tanggal 10 (sepuluh) bulan takwim berikutnya. Lapor paling lama tanggal 20 (dua puluh) bulan takwim berikutnya. Pajak Penghasilan Pasal 22, Bendahara, Dilunasi pada hari yang sama dengan pelaksanaan pembayaran atas penyerahan barang yang dibiayai dari belanja negara. Lapor paling lama 14 (empat belas) hari setelah bulan takwim berikutnya. Pajak Penghasilan Pasal 23/26, Dilunasi paling lambat tanggal 10 (sepuluh) bulan takwim berikutnya. Lapor

${ }^{20}$ Mardiasmo, Op. Cit, hlm. 285. 
paling lama tanggal 20 (dua puluh) bulan takwim berikutnya. Pajak Pertambahan Nilai dan Pajak Penjualan atas Barang Mewah, Dilunasi paling lambat tanggal 15 (lima belas) bulan takwim berikutnya. Lapor paling lama tanggal 20 (dua puluh) bulan takwim berikutnya.

Keterlambatan Pelaporan Pajak untuk Surat Pemberitahuan Masa Pajak Pertambahan Nilai dikenakan denda sebesar Rp 500.000 .00 (lima ratus ribu rupiah) dan untuk Surat Pemberitahuan Masa lainnya dikenakan denda sebesar Rp 100.000.00 (seratus ribu rupiah) dan Surat Pemberitahuan Tahunan Pajak Penghasilan Badan dikenakan denda sebesar Rp 1.000.000.00 (satu juta rupiah).

Sesuai dengan Peraturan Menteri Keuangan Nomor 80-PMK.03/2010 tentang Penentuan Tanggal Jatuh Tempo Pembayaran dan Penyetoran Pajak, Penentuan Tempat Pembayaran Pajak, dan Tata Cara Pembayaran, Penyetoran, dan Pelaporan Pajak, serta Tata Cara Pengangsuran dan Penundaan Pembayaran Pajak, diatur mengenai Penyetoran dan Pelaporan Pajak, sebagai berikut. Pasal 2 ayat (13) Pajak Pertambahan Nilai yang terutang atas kegiatan membangun sendiri harus disetor oleh orang pribadi atau badan yang melakukan kegiatan membangun sendiri paling lama tanggal 15 (lima belas) bulan berikutnya setelah Masa Pajak berakhir.

Pasal 2, ayat (13A) Pajak Pertambahan Nilai yang terutang atas pemanfaatan Barang Kena Pajak tidak berwujud dan/atau Jasa Kena Pajak dari luar Daerah Pabean harus disetor oleh orang pribadi atau badan yang memanfaatkan Barang Kena Pajak tidak berwujud dan/atau Jasa Kena Pajak dari luar Daerah Pabean, paling lama tanggal 15 (lima belas) bulan berikutnya setelah saat terutangnya pajak. Pasal 2, ayat (14) Pajak Pertambahan Nilai dan Pajak Penjualan atas Barang Mewah yang pemungutannya dilakukan oleh Bendahara Pengeluaran sebagai Pemungut Pajak Pertambahan Nilai, harus disetor paling lama tanggal 7 (tujuh) bulan berikutnya setelah Masa Pajak berakhir.

Pasal 2, ayat (14A) Pajak Pertambahan Nilai dan Pajak Penjualan atas Barang Mewah yang pemungutannya dilakukan oleh Pejabat Penandatangan Surat Perintah Membayar sebagai Pemungut Pajak Pertambahan Nilai, harus disetor pada hari yang sama dengan pelaksanaan pembayaran kepada Pengusaha Kena Pajak Rekanan Pemerintah melalui kantor Pelayanan Perbendaharaan Negara. Pasal 2, ayat (15) Pajak Pertambahan Nilai atau Pajak Pertambahan Nilai dan Pajak Penjualan atas Barang Mewah yang pemungutannya dilakukan oleh Pemungut Pajak Pertambahan Nilai selain Bendahara Pemerintah yang ditunjuk, harus disetor paling lama tanggal 15 (lima belas) bulan berikutnya setelah Masa Pajak berakhir. Pasal 2A Pajak Pertambahan Nilai dan Pajak Penjualan atas Barang Mewah yang terutang dalam satu Masa 
Pajak harus disetor paling lama akhir bulan berikutnya setelah Masa Pajak berakhir dan sebelum Surat Pemberitahuan Masa Pajak Pertambahan Nilai disampaikan.

Pelaporan Pajak Pertambahan Nilai Pasal 7 ayat (1A). Pengusaha Kena Pajak wajib melaporkan Pajak Pertambahan Nilai dan Pajak Penjualan atas Barang Mewah yang telah disetor sebagaimana dimaksud dalam Pasal 2 ayat (13) dan ayat (13A), serta Pasal (2A) dengan menggunakan Surat Pemberitahuan Masa Pajak Pertambahan Nilai ke Kantor Pelayanan Pajak tempat Pengusaha Kena Pajak dikukuhkan, paling lama akhir bulan berikutnya setelah Masa Pajak berakhir.

Pasal 7, ayat (1B). Orang pribadi atau badan yang bukan Pengusaha Kena Pajak wajib melaporkan Pajak Pertambahan Nilai yang telah disetor sebagaimana dimaksud dalam Pasal 2 ayat (13) dengan menggunakan lembar ketiga Surat Setoran Pajak ke Kantor Pelayanan Pajak yang wilayahnya meliputi tempat bangunan tersebut, paling lama akhir bulan berikutnya setelah Masa Pajak berakhir.

Pasal 7, ayat (1C). Orang pribadi atau badan yang bukan Pengusaha Kena Pajak wajib melaporkan Pajak Pertambahan Nilai yang telah disetor sebagaimana dimaksud dalam pasal 2 ayat (13A) dengan menggunakan lembar ketiga Surat Setoran Pajak ke Kantor Pelayanan Pajak yang wilayahnya meliputi tempat tinggal orang pribadi atau tempat kedudukan badan tersebut, paling lama akhir bulan berikutnya setelah saat terutangnya pajak.

Pasal 7, ayat (3). Pemungut Pajak sebagaimana dimaksud dalam Pasal 2 ayat (10) wajib melaporkan hasil pemungutannya paling lama 14 (empat belas) hari setelah Masa Pajak berakhir. Pasal 7, ayat (3A). Pemungut Pajak Pertambahan Nilai wajib melaporkan Pajak Pertambahan Nilai dan Pajak Penjualan atas Barang Mewah yang telah disetor sebagaimana dimaksud dalam Pasal 2 ayat (14) dan ayat (15) ke Kantor Pelayanan Pajak tempat Pemungut Pajak Pertambahan Nilai terdaftar paling lama akhir bulan berikutnya setelah Masa Pajak berakhir.

Adapun tarif dan pajak terutang tidak terlepas dari rasa keadilan, sebab keadilan dapat menciptakan keseimbangan social yang sangat penting untuk kesehajteraan masyarakat. Dalam penetapan tarif pajak harus berdasarkan pada prinsip-prinsip keadilan, dan juga kepastian. Dalam perhitungan pajak yang terutang digunakan tarif pajak.

Tarif pajak yang dimaksud adalah tarif untuk menghitung besarnya pajak terutang (pajak yang harus dibayar). Apabila melihat timbulnya utang pajak, bahwa utang pajak timbul karena Surat Keputusan Pajak, ajaran ini diterapkan pada official assessment system. Perbedaan 
ajaran materiil bahwa utang pajak timbul karena undang-undang. Ajaran ini diterapkan pada self assessment system.

Hapusnya utang pajak disebabkan antara lain ${ }^{21}$ adalah Pembayaran, Utang pajak yang melekat pada Wajib Pajak akan hapus karena pembayaran yang dilakukan ke Kas Negara. Kompensasi, Keputusan yang ditunjukkan kepada kompensasi utang pajak dengan tagihan seseorang diluar pajak tidak diperkenankan. Oleh karena itu kompensasi terjadi apabila Wajib Pajak mempunyai tagihan berupa kelebihan pembayaran pajak. Jumlah kelebihan pembayaran pajak yang diterima Wajib Pajak sebelumnya harus dikompensasikan dengan pajak-pajak lainnya yang terutang. Daluwarsa diartikan sebagai daluwarsa penagihan.

Hak untuk melakukan penagihan pajak, daluwarsa setelah lampau waktu sepuluh tahun terhitung sejak saat terutangnya pajak atau berakhirnya Masa Pajak, bagian tahun pajak atau tahun pajak yang bersangkutan. Hal ini untuk memberikan kepastian hukum kapan uang pajak tidak dapat ditagih lagi. Namun daluwarsa penagihan pajak tertangguh, antara lain, apabila diterbitkan Surat Teguran dan Surat Paksa. Pembebasan, Utang pajak tidak berakhir dalam arti yang semestinya tetapi karena ditiadakan. Pembebasan pada umumnya tidak diberikan terhadap pokok pajaknya, tetapi diberikan terhadap sanksi administrasinya. Penghapusan utang pajak ini sama sifatnya dengan pembebasan, tetapi diberikan karena keadaan keuangan Wajib Pajak.

Seperti yang telah disampaikan sebelumnya dalam Organisation for Economic Cooperation and Development (OECD) terdapat 28 jenis transaksi E-Commerce yang dilakukan secara online dan berpeluang dikenakan pajak salah satunya adalah Advertising/Banner Ads. Google Indonesia dalam hal ini melakukan transaksi E-Commerce yang dilakukan secara online yaitu Advertising/Banner Ads. Google Indonesia diklaim telah menghindari pajak (Tax Avoidance) oleh Direktorat Jenderal Pajak kepada Google Indonesia terkait dengan masalah pajak yang sekarang dihadapi oleh Google Indonesia. Direktorat Jenderal Pajak akan meningkatkan tahapan kearah investigasi karena Google Indonesia menolak untuk diperiksa. ${ }^{22}$ Google Indonesia dianggap menghindari pajak karena belum menjadi Badan Usaha Tetap (BUT), dengan kata lain Google Indonesia belum menjadi Wajib Pajak.

Selama ini Google hanya membuat kantor perwakilan di Indonesia, bukan kantor tetap. Oleh karena itu, transaksi bisnis Google yang terjadi di Indonesia tidak berpengaruh kepada

${ }^{21}$ Mulyo Agung, Perpajakan Indonesia Seri PPN dan PPnBM Teori Aplikasi Edisi Revisi Cetakan Pertama, Dinamika Ilmu, Jakarta, 2007, hlm. 15.

22 Reska K Nistanto, Masalah Pajak Yang Membelit Google di Indonesia, http://tekno.kompas.com/read/2016/09/19/09153207/masalah.pajak.yang.membelit.google.di.indonesia, 2016, di akses 20 September 17:45. 
peningkatan pendapatan negara. Padahal transaksi dalam periklanan (Advertising/Banner Ads) secara online yang dilakukan oleh Google pada tahun 2015 mencapai \$850 juta (Delapan ratus lima puluh juta) atau sekitar Rp 11.600.000.000.00 (Sebelas triliun enam ratus juta rupiah).

Menurut catatan Direktorat Jenderal Pajak, Google di Indonesia telah terdaftar sebagai badan hukum dalam negeri di Kantor Perwakilan Pajak (KPP) Tanah Abang III dengan status sebagai Penanaman Modal Asing (PMA) sejak 15 september 2011 dan merupakan dependent agent dari Google Asia Pacific Pte Ltd di Singapura. Dengan demikian, menurut Pasal 2 ayat (5) huruf (n) Undang-Undang Pajak Penghasilan, Google seharusnya berstatus sebagai BUT, sehingga setiap pendapatan maupun penerimaan yang bersumber dari Indonesia berhak dikenakan pajak penghasilan.

Negara-negara Organisation for Economic Co-operation and Development (OECD) telah sepakat bahwa pemungutan pajak penghasilan atas transaksi E-Commerce yang memiliki Bentuk Usaha Tetap (BUT) akan menggunakan asas sumber, jika tidak memiliki Badan Usaha Tetap maka akan digunakan asas domisili.

Penjelasan Badan Usaha Tetap menurut Pasal 2 ayat (5) Undang-Undang Pajak Penghasilan yaitu, Bentuk usaha tetap adalah bentuk usaha yang dipergunakan oleh orang pribadi yang tidak bertempat tinggal di Indonesia, orang pribadi yang berada di Indonesia tidak lebih dari 183 (seratus delapan puluh tiga) hari dalam jangka waktu 12 (dua belas) bulan, dan badan yang tidak didirikan dan tidak bertempat kedudukan di Indonesia untuk menjalankan usaha atau melakukan kegiatan di Indonesia, yang dapat berupa Tempat kedudukan manajemen, Cabang perusahaan, Kantor perwakilan, Gedung kantor, Pabrik, Bengkel, Gudang, Ruang untuk promosi dan penjualan, Pertambangan dan penggalian sumber alam, Wilayah kerja pertambangan minyak dan gas bumi, Perikanan, peternakan, pertanian, perkebunan, atau kehutanan, Proyek konstruksi, instalasi, atau proyek perakitan, Pemberian jasa dalam bentuk apapun oleh pegawai atau orang lain, sepanjang dilakukan lebih dari 60 (enam puluh) hari dalam jangka waktu 12 (dua belas) bulan.

Orang atau badan yang bertindak selaku agen yang kedudukannya tidak bebas, Agen atau pegawai dari perusahaan asuransi yang tidak didirikan dan tidak bertempat kedudukan di Indonesia yang menerima premi asuransi atau menanggung resiko di Indonesia, Komputer, agen elektronik atau peralatan otomatis yang dimiliki, disewa, atau digunakan oleh penyelenggara transaksi elektronik untuk menjalankan kegiatan usaha melalui internet.

\section{Kepastian Hukum Dalam Pelaporan Pajak Atas E-Commerce}


Negara Indonesia adalah negara hukum (rechtstaat), pernyataan ini tercantum di dalam Pasal 1 Ayat (3) Undang-Undang Dasar (UUD) 1945. Di dalam negara hukum, semua kebijakan diatur dalam suatu peraturan perundang-undangan. Dalam pelaksanaan kepastian hukum, tidak terlepas dari penegakan hukum, perlu adanya suatu penyuluhan hukum guna untuk mencapai kadar kesadaran hukum yang tinggi dalam masyarakat sehingga masyarakat dapat menghayati hak dan kewajiban dalam rangka tegaknya hukum, tegaknya keadilan, ketertiban hukum, kepastian hukum dan terbentuknya sikap dan perilaku yang taat hukum.

Asas certainty (kepastian) hukum yang terdapat dalam asas Case of Administration. Jika dikaitkan dengan kepastian hukum dalam pelaporan pajak atas transaksi E-Commerce sebelumnya, asas kepastian hukum menghendaki adanya kepastian, baik bagi petugas pajak maupun semua wajib pajak dan seluruh masyarakat. Asas kepastian ini mencakup kepastian mengenai subjek pajak, objek pajak, dasar pengenaan pajak serta besarnya tarif pajak, dan prosedur pemenuhan kewajiban pajak.

Asas kepastian dibedakan menjadi dua, yaitu kepastian hukum materil dan kepastian hukum formal. Kepastian dalam hukum materil mengatur ketentuan mengenai kepastian tentang siapa-siapa saja yang dikenakan pajak, siapa-siapa saja yang dikecualikan, apa-apa saja yang dikenakan pajak dan apa-apa saja yang dikecualikan serta besarnya pajak terutang. Sedangkan kepastian hukum formal mengatur kepastian mengenai prosedur (tata cara) pemenuhan hak dan kewajiban perpajakan serta sanksi-sanksi bagi yang melanggar kewajiban perpajakan.

Prosedur pemenuhan kewajiban pajak antara lain prosedur pembayaran dan pelaporan pajak serta pelaksanaan hak-hak perpajakannya. Dalam hal ini telah ada prosedur (Legal Formil) yang jelas dan tegas dan diatur dalam Peraturan Perundang-undangan yang jelas, sehingga wajib pajak lebih mudah menjalankan kewajiban serta haknya dan bagi fiskus akan lebih mudah untuk mengawasi pelaksanaan kewajiban perpajakkan yang dilakukan oleh wajib pajak juga dalam melayani hak-hak wajib pajak. Dalam hal ini untuk memberikan kepastian hukum kepada wajib pajak dalam hal pelaporan pajak telah jelas dan tegas diatur dalam Peraturan Direktorat Jenderal Pajak Nomor KEP-47/PJ./2008. Dengan didukung hukum pajak formal yang jelas dan tegas, tentunya hukum materil akan bisa dilaksanakan oleh wajib pajak dan fiskus dengan melakukan pengawasan atau Law Enforcement. 
Asas kepastian hukum juga menghendaki dihormatinya hak yang telah diperoleh seseorang berdasarkan suatu keputusan badan atau pejabat administrasi negara. ${ }^{23}$ Asas kepastian hukum ini adalah asas dalam negara hukum yang mengutamakan landasan peraturan perundang-undangan, kepatutan, dan keadilan dalam setiap kebijakan penyelenggara negara. ${ }^{24}$

Dalam hal ini Direktorat Jenderal Pajak harus melaksanakan fungsi sebagai fiskus, Direktorat Jenderal Pajak sebagai fiskus harus mematuhi dan memegang suatu asas-asas pemerintahan yang baik yang telah ditentukan oleh peraturan perundang-undangan. Direktorat Jenderal Pajak dalam melakukan setiap tindakan untuk menjalankan funsinya harus berdasarkan pada peraturan perundang-undangan yang telah ada, kepastian, keadilan, dan kepatutan.

Pelaporan pajak dan penyampaian Surat Pemberitahuan (SPT) yang dilakukan melalui sistem online atau dikenal dengan e-Filing melalui perusahaan Penyedia Jasa Aplikasi (ASP) dilaksanakan berdasarkan ketentuan yang telah diatur oleh Direktorat Jenderal Pajak melalui KEP-47/PJ./2008 tentang Tata Cara Penyampaian Surat Pemberitahuan dan Penyampaian Pemberitahuan Perpanjangan Surat Pemberitahuan Tahunan secara elektronik (e-Filing) melalui perusahaan Penyedia Jasa Aplikasi. Dalam melakukan pelaporan pajak dan penyampaian Surat Pemberitahuan melalui sistem $e$-Filing terdapat suatu kepastian dan perlindungan hukum bagi wajib pajak.

Adapun penerapan E-Filing adalah suatu cara penyampaian Surat Pemberitahuan secara elektronik yang dilakukan secara online dan real time melalui Internet pada website Direktorat Jenderal Pajak atau Penyedia Layanan Surat Pemberitahuan Elektronik atau Application Service Provider (ASP). Direktorat Jenderal Pajak memutuskan bahwa "Wajib Pajak dapat menyampaikan Surat Pemberitahuan secara elektronik melalui perusahaan penyedia jasa aplikasi (Application Service Provider) yang ditunjuk oleh Direktorat Jenderal Pajak".

E-Filing merupakan bagian dari sistem dalam administrasi pajak yang digunakan untuk menyampaikan Surat Pemberitahuan secara online yang real time kepada kantor pajak. Jadi dalam penerapan sistem E-Filing adalah suatu proses atau cara memanfaatkan sistem yang digunakan untuk menyampaikan Surat Pemberitahuan secara online yang real time yang diterapkan oleh Direktorat Jenderal Pajak.

Penerapan sistem E-Filing memiliki beberapa keuntungan bagi Wajib Pajak melalui situs website Direktorat Jenderal Pajak yaitu Penyampaian Surat Pemberitahuan lebih cepat karena dapat dilakukan dimana saja dan kapan saja yaitu 24 jam sehari, 7 hari dalam seminggu

${ }^{23}$ SF Marbun Moh Mahfud MD, Pokok-Pokok Hukum Administrasi Negara, Jakarta, 2006, hlm. 60.
${ }^{24}$ Lutfi Effendi, Pokok-Pokok Hukum Administrasi, Bayumedia Publishing, Malang, 2004, hlm. 86. 
karena memanfaatkan jaringan Internet, Biaya pelaporan Surat Pemberitahuan lebih murah karena untuk mengakses situs website Direktorat Jenderal Pajak tidak dipungut biaya, Penghitungan dilakukan secara cepat karena menggunakan sistem computer, Lebih mudah karena pengisian Surat Pemberitahuan dalam bentuk wizard, Data yang disampaikan Wajib Pajak selalu lengkap karena terdapat validasi pengisian Surat Pemberitahuan, Lebih ramah lingkungan karena meminimalisir penggunaan kertas, Dokumen pelengkap tidak perlu dikirim lagi kecuali diminta oleh Kantor Pelayanan Pajak melalui Account Representative.

Direktorat Jenderal Pajak melakukan reformasi perpajakan yang selaras dengan dinamika perekonomian dan dunia usaha agar dapat mewujudkan sistem perpajakan yang adil kompetitif, dan memberikan kepastian hukum. Pada tahun 2009 Direktorat Jenderal Pajak meluncurkan apa yang disebut sebagai reformasi jilid II, hal ini karena berdasarkan analisis yang dilakukan, diketahui masih terdapat selisih antara jumlah potensi pajak yang dapat dipungut (taxes owed) dengan jumlah realisasi penerimaan pajak (taxes paid) yang dikenal dengan istilah Tax Gap yang cukup lebar yang menggambarkan jumlah potensi pajak yang belum disetorkan ke kas negara.

Reformasi Pajak Jilid II tersebut antara lain, Peningkatan pelatihan dan pendidikan pegawai baik didalam maupun diluar negeri, Remunerasi tenaga pemeriksa dan juru sita dievaluasi, Sistem reward dan punishment yang ditegakan secara adil dan ketat, Pembentukan Kantor Pelayanan Pajak (KPP) Wajib Pajak Besar Orang Pribadi (High Wealth Individual), Peningkatan efisiensi sistem Modul Penerimaan Negara (MPN) sehingga Wajib Pajak membayar pajak, dilayani dengan waktu luas tanpa terlalu banyak syarat administrasi bank ke Direktorat Jenderal Perbendaharaan dan juga laporan yang tanpa jeda waktu ke Direktorat Jenderal Pajak, Kerjasama dengan expert kelas dunia untuk menyiapkan perbaikan lanjutan di Direktorat Jenderal Pajak meliputi seluruh aspek dari core bisnis Direktorat Jenderal Pajak yaitu Project for Indonesian Tax Administration Reform (PINTAR) dan, Perluasan inbound dan outbound call center.

Tujuan dari penyebarluasan undang-undang pajak adalah dalam rangka ekstensifikasi dan intensifikasi pengenaan dan pemungutan pajak yang sekaligus merupakan upaya peningkatan keadilan pajak, penghapusan fasilitas pajak yang tidak memiliki landasan hukum yang akan merugikan perekonomian nasional dan menutup celah penghindaran pajak (Loopheles).

Dalam rangka melaksanakan pembaruan yang terus dilaksanakan Direktorat Jenderal Pajak terus meningkatkan upaya dalam peningkatan penerimaan negara terhadap pajak. Pada 
tahun 2002 Direktorat Jenderal Pajak meluncurkan program perubahan atau secara singkat yang dimaksud dengan modernisasi perpajakan ialah reformasi terhadap administrasi perpajakan.

Penerapan program administrasi ini dilakukan dengan mengoptimalisasi sistem administrasi dengan pemanfaatan teknologi yang handal dan terkini. Dalam mewujudkan modernisasi perpajakan terdapat perubahan-perubahan yang dilakukan meliputi berbagai bidang berikut, ${ }^{25}$ Struktur Organisasi, Business process dan teknologi informasi dan komunikasi, Manajemen sumber daya manusia, Pelaksanaan good governance.

Berdasarkan uraian tersebut, penjelasan dari keempat bidang tersebut ialah Struktur Organisasi, dalam mengimplementasikan konsep administrasi perpajakan modern yang berorientasi terhadap pelayanan dan pengawasan, maka Direktorat Jenderal Pajak perlu mengubah struktur organisasinya, perubahan struktur organisasi ini diterapkan dari level kantor pusat sampai kantor operasional.

Sebagai langkah awal untuk memudahkan Wajib Pajak dalam menyelesaikan kewajiban perpajakannya Direktorat Jenderal Pajak melebur Kantor Pelayanan Pajak Bumi dan Bangunan (KPPBB), Kantor Pelayanan Pajak (KPP), serta Kantor Pemeriksaan dan Penyidikan Pajak (Karikpa) menjadi satu kantor dalam mengurus segala urusan perpajakan yaitu Kantor Pelayanan Pajak (KPP). Unit vertical Direktorat Jenderal Pajak dibedakan berdasarkan segmentasi Wajib Pajak, yaitu Kantor Pelayanan Pajak Wajib Pajak Besar (LTO-Large Tax Payers Office), Kantor Pelayanan Pajak Madya (MTO-Medium Tax payers Office), dan Kantor Pelayanan Pajak Pratama (STO-Small Tax Payers Office).

Peningkatan seperti ini, diharapkan mampu meningkatkan strategi dan pendekatan terhadap Wajib Pajak yang disesuaikan dengan karakteristik Wajib Pajak yang ditangani. Khusus pada kantor operasional, dibuat posisi baru yang disebut Account Representative, tugas dari posisi ini adalah memberikan bantuan konsultasi perpajakan kepada Wajib Pajak, memberitahukan peraturan perpajakan yang baru, dan mengawasi kepatuhan Wajib Pajak.

Business Process dan Teknologi Informasi dan Komunikasi, Direktorat Jenderal Pajak melakukan perbaikan Business Process dalam rangka memperbaiki metode, sistem, dan prosedur kerja untuk memperbaiki birokrasi yang berbelit-belit. Business process dirancang untuk mengurangi kontak langsung antara pegawai Direktorat Jenderal Pajak dengan Wajib Pajak.

Langkah pertama dalam perbaikan business process penulisan dan dokumentasi Standar Operating Procedures (SOP) yang diterapkan pada setiap kegiatan di Direktorat Jenderal Pajak.

${ }^{25}$ Diana Sari, Konsep Dasar Perpajakan, PT Refika Aditama, Bandung, 2013, hlm. 14. 
Sampai akhir tahun 2007 Direktorat Jenderal Pajak telah berhasil mengidentifikasi 1900 Standar Operating Procedures (SOP). Selain penulisan Standar Operating Procedures (SOP), Direktorat Jenderal Pajak banyak melakukan optimalisasi pada teknologi informasi dan komunikasi dalam memudahkan Wajib Pajak dalam memenuhi kewajiban perpajakannya, hal ini terlihat dengan penerapan E-System dengan dibukanya fasilitas E-Filing (pengiriman Surat Pemberitahuan secara online melalui Internet), e-SPT (penyerahan Surat Pemberitahuan dalam media digital), e-Payment (fasilitas pembayaran online untuk Pajak Bumi dan Bangunan), dan e-Registration (pendaftaran Nomor Pokok Wajib Pajak secara online melalui Internet).

Manajemen Sumber Daya Manusia, Selain perbaikan dan pengoptimalisasi penggunaan sistem teknologi, Direktorat Jenderal Pajak menyadari bahwa fokus utama dari reformasi perpajakan adalah perbaikan dari manajemen sumber daya manusia, karena elemen utama dari organisasi adalah manusianya. Pelaksanaan Good Governance, Unit elemen terakhir dalam modernisasi perpajakan adalah Pelaksanaan Good Governance. Program ini sering dihubungkan dengan integritas pegawai dan institusi. Hal ini menerangkan bahwa sebuah organisasi akan berjalan dengan sesuai manakala suatu organisasi memiliki rambu-rambu yang jelas dalam memandu pelaksanaan tugas dan pekerjaannya serta adanya konsistensi terhadap implementasi rambu-rambu tersebut.

Salah satu agenda reformasi perpajakan yang dicanangkan oleh Pemerintah Indonesia adalah melakukan ekstensifikasi dan intensifikasi perpajakan. Hal ini berkaitan dengan upaya peningkatan penerimaan negara dari sektor pajak yang sekaligus upaya peningkatan jumlah subjek dan objek pajak. Mengimplementasikan kebijakan yang berkaitan dengan pengampunan pajak (Tax Amnesty) merupakan salah satu agenda reformasi di bidang perpajakan di Indonesia.

Tax amnesty adalah suatu kesempatan waktu yang terbatas pada kelompok pembayar pajak tertentu untuk membayar sejumlah tertentu dan dalam waktu tertentu berupa pengampunan kewajiban pajak (termasuk bunga dan denda) yang berkaitan dengan masa pajak sebelumnya atau periode tertentu tanpa takut hukuman pidana. Ini biasanya berakhir ketika otoritas yang dimulai penyelidikan pajak masa lalu. Dalam beberapa kasus, undang-undang amnesty yang memperpanjang juga membebankan hukuman yang lebih berat pada mereka yang memenuhi syarat untuk amnesty tetapi tidak mengambilnya. ${ }^{26}$

Kebijakan Tax Amnesty sebenarnya pernah dilakukan Indonesia pada tahun 1984. Demikian juga kebijakan lain yang serupa berupa Sunset Policy telah dilakukan pada tahun

${ }^{26}$ Ragimun, Analisis Implementasi Pengampunan Pajak (Tax Amnesty) di Indonesia, www.kemenkeu.go.id, di akses 12 September 2016 18:43, hlm. 8. 
2008. Sejak Program Sunset Policy di implementasikan sepanjang tahun 2008 telah berhasil menambah jumlah Nomor Pokok Wajib Pajak baru sebanyak 5.653.128 (lima juta enam ratus lima puluh tiga ribu seratus dua puluh delapan) Nomor Pokok Wajib Pajak, bertambahnya Surat Pemberitahuan Tahunan sebanyak 804.814 (delapan ratus empat ribu delapan ratus empat belas) Surat Pemberitahuan dan bertambahnya penerimaan Pajak Penghasilan sebesar Rp 7.460.000.000.000.00 (tujuh triliun empat ratus enam puluh miliar rupiah) Jumlah Nomor Pokok Wajib Pajak Orang Pribadi 15,07 (lima belas koma tujuh) juta, Nomor Pokok Wajib Pajak Bendaharawan 447.000 (empat ratus empat puluh tujuh ribu) dan Nomor Pokok Wajib Pajak Badan Hukum 1,63 (satu koma enam puluh tiga) juta. Jadi totalnya 17,16 (tujuh belas koma enam belas) juta, berdasarakan data Direktorat Jenderal Pajak, 2010 kuartal 1.

Dengan adanya Undang-Undang Nomor 11 Tahun 2016 tentang Pengampunan Pajak (Tax Amnesty) dapat memberikan kepastian hukum dan dapat mendorong masuknya dana-dana dari luar negeri yang dalam jangka panjang dapat digunakan sebagai pendorong investasi yang pada gilirannya bermanfaat untuk menstimulasi perekonomian nasional. Dalam menetapkan perlu tidaknya Tax Amnesty, perlu dipertimbangkan apa yang menjadi justifikasi dari Tax Amnesty dan hingga batas mana Tax Amnesty dapat dijustifikasi. Pada umumnya, pemberian Tax Amnesty bertujuan untuk $^{27}$ Meningkatkan Penerimaan Pajak Dalam Jangka Pendek, Permasalahan penerimaan pajak yang stagnan atau cenderung menurun seringkali menjadi alasan pembenar diberikannya Tax Amnesty. ${ }^{28}$

Hal ini berdampak pada keinginan pemerintah yang berkuasa untuk memberikan Tax Amnesty dengan harapan pajak yang dibayar oleh Wajib Pajak selama program Tax Amnesty akan meningkatkan penerimaan pajak. Meski demikian, peningkatan penerimaan pajak dari program Tax Amnesty ini mungkin saja hanya terjadi selama program Tax Amnesty dilaksanakan mengingat Wajib Pajak bisa saja kembali kepada perilaku ketidakpatuhannya setelah Program Tax Amnesty berakhir. Dalam jangka panjang, pemberian Tax Amnesty tidak memberikan banyak pengaruh yang permanen terhadap penerimaan pajak jika tidak dilengkapi dengan program peningkatan kepatuhan dan pengawasan kewajiban perpajakan. ${ }^{29}$

Meningkatkan kepatuhan pajak di masa yang akan datang, Permasalahan kepatuhan pajak merupakan salah satu penyebab pemberian Tax Amnesty. Para pendukung Tax Amnesty umumnya berpendapat bahwa kepatuhan sukarela akan meningkat setelah program Tax

${ }^{27}$ Danny Darussalam, Tax Amnesty Dalam Rangka Rekonsiliasi Nasional, Inside Tax Edisi 26, 2014, hlm. 15.

${ }^{28}$ Peter Stella, An Economic Analysis of Tax Amnesties, IMF Working Paper No. WP/89/42, 1989.

29 James Alm, Jorge Martinez-Vazquez and Sally Walace, Do Tax Amnesties Work?: The Revenue Effect of Tax Amnesties During the Transition of Russian Federation, Economic Analysis and Policy Vol 39, 2009, hlm. 249. 
Amnesty dilakukan. ${ }^{30}$ Hal ini didasari pada harapan bahwa setelah program Tax Amnesty dilakukan Wajib Pajak yang sebelumnya belum menjadi bagian dari sistem administrasi perpajakan akan masuk menjadi bagian dari sistem administrasi perpajakan. Dengan menjadi bagian dari sistem administrasi perpajakan, maka Wajib Pajak tersebut tidak akan bisa mengelak dan menghindar dari kewajiban perpajakannya. Mendorong Repatriasi Modal atau Aset, Kejujuran dalam pelaporan sukarela atas data harta kekayaan setelah program Tax Amnesty merupakan salah satu tujuan pemberian Tax Amnesty.

Dalam konteks pelaporan data harta kekayaan tersebut, pemberian Tax Amnesty juga bertujuan untuk mengembalikan modal yang parker di luar negeri tanpa perlu membayar pajak atas modal yang di parkir di luar negeri tersebut. Pemberian Tax Amnesty atas pengembalian modal yang di parkir di luar negeri ke bank di dalam negeri dipandang perlu karena akan memudahkan otoritas pajak dalam meminta informasi tentang data kekayaan Wajib Pajak kepada bank di dalam negeri. Transisi Sistem Perpajakan Yang Baru, Tax Amnesty dapat dijustifikasi ketika Tax Amnesty digunakan sebagai alat transisi menuju sistem perpajakan yang baru. ${ }^{31}$ Dalam konteks ini, Tax Amnesty menjadi instrument dalam rangka memfasilitasi reformasi perpajakan dan sebagai kompensasi atas penerimaan pajak yang berpotensi hilang dari transisi ke sistem perpajakan yang baru tersebut.

Pengampunan pajak (Tax Amnesty) seringkali dijadikan alat untuk menghimpun penerimaan negara dari sektor pajak (Tax Revenue) secara cepat dalam jangka waktu yang relatif singkat. Program Tax Amnesty ini dilaksanakan karena semakin parahnya upaya penghindaran pajak. Kebijakan ini dapat memperoleh manfaat perolehan dana, terutama kembalinya dana yang disimpan diluar negeri, dan kebijakan ini dalam mempunyai kelemahan dalam jangka panjang dapat berakibat buruk berupa menurunnya kepatuhan sukarela (voluntary compliance) yang berdampak terhadap kepastian hukum tentunya dari Wajib Pajak, bilamana Tax Amnesty dilaksanakan dengan program yang tidak tepat. Mengenai pelaksanaan Tax Amnesty di beberapa negara yang relatif lebih berhasil dalam melaksanakan kebijakan pengampunan pajak seperti di Afrika Selatan, Irlandia dan India, dengan maksud untuk mempelajari kebijakan dari masing-masing negara serta menganalisis faktor yang menyebabkan

30 James Alm, Tax Policy Analysis: the Introduction of a Russian Tax Amnesties, International Studies Program Working Paper 98-6, Georgia State University Andrew Young School of Policy Studies, 1998, hlm. 3.

${ }^{31}$ Jacques Malherbe, Tax Amnesties in The 2009 Landscape, Bulletin for International Taxation, 2010, hlm. 241. 
program ini dapat berhasil dan mencapai target yang ditetapkan, serta perspektifnya bagi pelaku bisnis. $^{32}$

Tax Amnesty memberikan gambaran tentang karakteristik dari suatu program Tax Amnesty, sebagai berikut ${ }^{33}$ Durasi, Secara umum, program Tax Amnesty berlangsung dalam suatu kurun waktu tertentu dan umumnya berjalan selama 2 bulan hingga 1 tahun. Untuk mendukung berhasilnya program Tax Amnesty, hal yang perlu ditekankan adalah luasnya publisitas dan promosi program Tax Amnesty serta tersampaikannya pesan bahwa Wajib Pajak hanya memiliki kesempatan sekali ini saja untuk memperoleh pengampunan atas pajak yang terutang, bunga, dan/atau sanksi administrasi.

Pengampunan pajak, ${ }^{34}$ sebaiknya diberikan hanya sekali saja dalam suatu generasi (once per generation). Pengampunan pajak yang diberikan berkali-kali menyebabkan Wajib Pajak akan selalu menunggu program pengampunan pajak berikutnya dan ini akan mendorong Wajib Pajak untuk tidak menjalankan kewajiban pajaknya dengan benar. Oleh karena itu, apabila pemerintah akan memberikan Tax Amnesty maka tidak boleh ada isu tentang program pengampunan pajak jilid berikutnya.

Kelompok Wajib Pajak, Secara umum, setiap Wajib Pajak yang belum menunaikan kewajiban perpajakannya diperbolehkan untuk berpartisipasi dalam program Tax Amnesty. Artinya, program Tax Amnesty ini ditujukan kepada Wajib Pajak yang telah berada dalam sistem administrasi perpajakan. Perlakuan yang berbeda dimungkinkan ketika Wajib Pajak yang hendak berpartisipasi dalam program Tax Amnesty telah diperiksa atau sedang dalam proses pemeriksaan. Dalam hal ini, Wajib Pajak yang telah diperiksa atau sedang dalam proses pemeriksaan tersebut tidak diperbolehkan berpartisipasi dalam program Tax Amnesty karena jumlah tunggakan pajaknya telah diketahui otoritas pajak.

Wajib Pajak juga dapat disebut diberikan pengampunan jika ketentuan peraturan perundang-undangan menyatakan Wajib Pajak yang mengungkapkan kewajiban perpajakan atau harta kekayaan secara sukarela berhak mendapatkan penurunan atau penghapusan sanksi administrasi. Jenis Pajak dan Jumlah Pajak atau Sanksi Administrasi yang diberikan ampunan, Ketentuan tentang Tax Amnesty harus menspesifikasi pajak apa saja yang diberikan ampunan. Pada umumnya, pajak yang diberikan ampunan hanya bersumber dari satu jenis pajak atau satu

\footnotetext{
32 Urip Santoso dan Justina Setiawan, Tax Amnesty dan Pelaksanaannya di Beberapa Negara: Perspektif Bagi Pebisnis Indonesia, Kopertis, Volume 11 Nomor 2 Juli 2009.

${ }^{33}$ Danny Darussalam, Op. Cit, hlm. 16.

34 Benno Torgler and Christoph A. Schaltegger, Tax Amnesties in Switzerland and Around the World, Tax Notes International, 2005, hlm. 1203.
} 
kategori subjek pajak saja, misalnya Tax Amnesty hanya diberikan pada Pajak Penghasilan Orang Pribadi saja tidak termasuk Pajak Penghasilan Badan, atau program Tax Amnesty hanya dikhususkan kepada Pajak Bumi dan Bangunan saja.

\section{V.PENUTUP}

\section{A. Kesimpulan}

Berdasarkan uraian yang telah dilakukan berdasarkan permasalahan dan pembahasan, maka dapat diambil kesimpulan sebagai berikut:

1. Peraturan perundang-undangan yang mengatur pajak E-Commerce terkait dengan penerbitan SE-62/PJ/2013 belum dapat terlaksana secara efektif karena penerbitan SE62/PJ/2013 ini hanya menegaskan bahwa tidak ada perbedaan di dalam transaksi yang dilakukan dengan cara biasa maupun online. Budaya tentang Wajib Pajak yang lebih spesifik terkait penerbitan SE-62/PJ/2013 ini belum dapat dijadikan sebagai acuan dalam transaksi yang dilakukan secara elektronik karena sesungguhnya transaksi biasa dan transaksi online berbeda secara spesifik maupun prosedur.

2. Laporan pajak terutang atas transaksi yang dilakukan melalui E-Commerce masih kurang efektif terkait Peraturan Pemerintah No 31 Tahun 2012 tentang Pemberian dan Penghimpunan Data dan Informasi yang berkaitan dengan perpajakan belum dapat terlaksana dengan baik, dan kurangnya data yang dimiliki oleh Direktorat Jenderal Pajak sehingga tidak semua Wajib Pajak dapat melaporkan pajak terutangnya karena transaksi yang dilakukan secara E-Commerce ini bukan saja dilakukan di dalam Negara Indonesia. Sehingga harus jelas siapa subjek, objek dan Negara mana yang berhak untuk memberikan pajak atas transaksi yang dilakukan melalui E-Commerce.

3. Kepastian hukum di dalam pelaporan pajak atas transaksi E-Commerce terkait dengan E-Filing, Tax Amnesty maupun Transaksi Perdagangan Melalui Sistem Elektronik belum dapat di implementasikan secara efektif di Indonesia, karena belum mempunyai payung hukum sebagai dasar serta tujuan yang jelas dalam pelaksanaannya. Direktorat Jenderal Pajak harusnya melakukan sosialisasi terlebih dahulu agar Transaksi Perdagangan Melalui Sistem Elektronik ini dapat terlaksana secara baik, dengan adanya kepastian hukum maka seharusnya jelas memuat apa saja yang menjadi tanggung jawab sebagai objek dan subjek pajak.

\section{B. Saran}


1. Seharusnya peraturan perundang-undangan dan SE-62/PJ/2013 harusnya benar-benar dapat mempertimbangkan pengaruh kedepannya nanti, tentu saja hal ini dapat dilakukan oleh Direktorat Jenderal Pajak dalam mempertimbangkan regulasi perpajakannya atas transaksi E-Commerce, yaitu dengan bekerja sama dengan pihak-pihak terkait, seperti APJII dan Departemen Komunikasi dan Informasi. Memperhatikan sistem pemungutan pajak yang efektif dan mempertimbangkan modernisasi sistem administrasi perpajakan.

2. Seharusnya laporan pajak terutang yang dihasilkan dari transaksi atas E-Commerce ini dapat dilakukan dengan pendekatan Harmonisasi dan Konvergensi agar kepastian hukum dalam pelaporan pajak atas transaksi elektronik dapat terlaksana dengan sebaikbaiknya. Dalam penetapan tarif pajak harus berdasarkan pada prinsip-prinsip keadilan dan juga kepastian hukum sehingga akan menjadi jelas objek dan subjek pajaknya.

3. Seharusnya kepastian hukum di dalam pelaporan pajak atas transaksi elektronik dapat dilakukan dengan memberikan kejelasan di dalam perundang-undangan yang terkait karena melihat dampak E-Commerce yang setiap hari semakin pesat perkembangannya. Pemerintah seharusnya lebih sigap lagi dalam melakukan pemberian kebijakan pengampunan pajak (tax amnesty) yang semestinya tidak hanya menghapus Hak Tagih atas Wajib Pajak tetapi seharusnya memperbaiki kepatuhan Wajib Pajak, sehingga pada jangka panjang dapat meningkatkan penerimaan pajak, dan tentu saja akan jelas nantinya tanggung jawab subjek dan objek pajak dalam memberikan laporan pajaknya.

\section{DAFTAR PUSTAKA}

\section{A. Sumber Buku}

Achmad Ali, Menguak Tabir Hukum (Suatu Kajian Filosofis dan Sosiologis), Penerbit Toko Gunung Agung, Jakarta, 2002.

Achmad Tjahjono dan Muhammad Fakhri Husein, Perpajakan, Akademi Manajemen Perusahaan YKPN, Yogyakarta, 2005, ed. 3, cet.ke 1.

Ahmad Mujahid Ramli, Cyber Law dan HAKI Dalam Sistem Hukum Indonesia, Refika Aditama, Bandung 2004.

B. Usman dan K. Subroto, Pajak Indonesia, Gramedia Pustaka Utama, Jakarta, 1995.

Bohari, Pengantar Hukum Pajak, cet.6, PT. Raja Grafindo Persada, Jakarta, 2006.

Budi Sutedja. D.O, E-education konsep teknologi dan aplikasi internet pendidikan, C.V. Andi Offset, Yogyakarta, 2007.

C.F.G, Sunarjati Hartono, Politik Hukum Menuju Satu Sistem Hukum Nasional, Alumni, Bandung, 1991.

Dardji, Darmodiharjo Pokok-Pokok Filsafat Hukum, Apa dan Bagaimana Filsafat Hukum Indonesia, PT. Gramedia PustakaUtama, Jakarta, 2006. 
Devano, Sony dan Siti Kurnia Rahayu, Perpajakan: konsep, teori dan isu, Kencana, Jakarta, 2006.

Diana Sari, Konsep Dasar Perpajakan, PT Refika Aditama, Bandung, 2013.

Djamaluddin Gede, Hukum Pajak, Lembaga Penerbit Fakultas Ekonomi Indonesia, Jakarta, 2002.

Djoko Slamet Surjoputro, Buku Panduan Hak dan Kewajiban Wajib Pajak, Direktorat Penyuluhan Pelayanan dan Humas, Jakarta, 2009.

Dominikus Rato, Filsafat Hukum Mencari: Memahami dan Memahami Hukum, Laksbang Pressindo, Yogyakarta, 2010.

Erly Suandy, Hukum Pajak (Dilengkapi dengan latihan soal), Salemba Empat, Jakarta, 2002.

Elfis Wandi, Analisis Efisiensi dan Efektivitas Pemungutan Pajak Hiburan Mifan Terhadap Pendapatan Asli Daerah Kota Padang Panjang, Jurnal Akuntansi, www.upi.yptk.ac.id Padang, 2013.

Fahmi M. Ahmadi. Jaenal Arifin, Metode Penelitian Hukum, Lembaga Penelitian UIN Syarif Hidayatullah, Jakarta, 2010.

Fathul Wahid, Kamus Istilah Teknologi Informasi, C.V. Andi Offset, Yogyakarta, 2002.

Gustian Djuanda Irwansyah Lubis, Pelaporan Pajak Pertambahan Nilai Dan Pajak Penjualan Atas Barang Mewah, PT Gramedia Pustaka Utama, Jakarta, 2011.

Hanny Kamarga, Belajar Sejarah Melalui E-Learning: Alternatif mengakses sumber informasi kesejarahan, Inti Media, Jakarta, 2002.

Haula Rosdiana, dan Rasin Tarigan, Perpajakan: Teori dan Aplikasi, PT. Raja Grafindo Persada, Jakarta, 2005.

dan Edi Slamer Irianto, Pengantar Ilmu Pajak: Kebijakan dan Implementasi di Indonesia, PT. Raja Grafindo Persada, Jakarta, 2012.

Herry Purnomo dan Theo Zacharias, Pengenalan Informasi Perspektif Teknis dan Lingkungan, CV. Andi Offset, Yogyakarta, 2004.

Laudin Marsuni, Hukum dan Kebijakan Perpajakan di Indonesia, UII Press, Yogyakarta, 2006.

Lia Sautunnida, Jual Beli Melalui Internet, Sinar harapan, Bandung, 2008.

Lili Rasyidi \& Ira Rasyidi, Dasar-Dasar Filsafat dan Teori Hukum, Citra Aditya Bakti, Bandung, 2001.

Lutfi Effendi, Pokok-Pokok Hukum Administrasi, Bayumedia Publishing, Malang, 2004.

Mansury R, Kebijakan Perpajakan, YP4, Jakarta, 2000.

Pajak Penghasilan Lanjutan Pasca Reformasi 2000, YP4, Jakarta, 2005.

Mardiasmo, Otonomi dan Manajemen Keuangan Daerah, ANDI, Yogyakarta, 2002.

, Perpajakan Edisi Revisi 2011, Andi Jogjakarta, Jogjakarta, 2011.

Mariam Darus Badrulzaman, Aneka Hukum Bisnis, Alumni, Bandung 1994.

Melwin Syafrizal, Pengantar Jaringan Komputer, C.V. Andi Offset, Yogyakarta, 2005.

Muhammad Djafar Saidi, Pembaruan Hukum Pajak, PT.Raja Grafindo Persada, Jakarta, 2007.

Mulyo Agung, Perpajakan Indonesia Seri PPN dan PPnBM Teori Aplikasi Edisi Revisi Cetakan Pertama, Dinamika Ilmu, Jakarta, 2007.

Muqodim, Perpajakan Buku Satu, UII Press, Yogyakarta, 1999.

Moctar Kusumaatmadja, Pembinaan Hukum Dalam Pembangunan Nasional, Bina Cipta Bandung, 1982.

Moleong J. Lexy, Metode Penelitian Kualitatif, PT. Remaja Roda Karya, Bandung 2004.

Nufransa Wira Sakti, Buku Pintar Pajak E-Commerce, Visimedia, Jakarta, 2014.

Onno W. Purbo dan Aang Arif Wahyudi, Mengenal e-Commerce, Elex Media Komputindo, Jakarta, 2001.

P. J. A. Andriani, Pajak dan Pembangunan, UI Press, Jakarta, 2000.

Panggih P. Dwi Atmojo, Internet Untuk Bisnis I, Dirkomnet Training, Jogjakarta, 2002. 
Peter Mahmud Marzuki, Pengantar Ilmu Hukum, Kencana, Jakarta, 2008.

R. Santoso Brotodihardjo, Pengantar Ilmu Hukum Pajak, Eresco, Bandung.

Riduan Syahrani, Rangkuman Intisari Ilmu Hukum, Penerbit Citra Aditya Bakti,Bandung, 1999. Rachmat Soemitro, Pengantar Singkat Hukum Pajak, Eresco, Bandung, 1987.

Ronny Hanitjo Soemitro, Metodologi Penelitian Hukum dan Jurimetri, Ghalia Indonesia, Jakarta, 1990.

Safri Nurmantu, Pengantar perpajakan, edisi 2, Granita, Jakarta, 2003.

SF Marbun Moh Mahfud MD, Pokok-Pokok Hukum Administrasi Negara, Liberty, 2006.

Siti Resmi, Perpajakan Teori dan Kasus, Buku I, Salemba Empat, Jakarta, 2003.

Soerjono Soekanto, Pengantar Penelitian Hukum, UI Press, Jakarta, 1986.

Mariam Darus Badrulzaman, Sutan Remy Sjahdeini, Heru Soepraptomo, Faturrahman Djamil, dan Taryana Soenandar, Kompilasi Hukum Perikatan, Citra Aditya Bakti, Jakarta, 2001.

Y. Sri Pudyatmoko, Pengantar Hukum Pajak, Lembaga Penerbit Andi, Yogyakarta, 2009.

Waluyo, Perpajakan Indonesia, Edisi 10 Buku 1, Salemba Empat, Jakarta, 2011.

\section{B. Peraturan perundang-undangan}

Undang-Undang Dasar Tahun 1945 Amandement Keempat.

Undang-Undang Nomor 11 Tahun 2016 Tentang Pengampunan Pajak (Tax Amnesty).

Undang-Undang Nomor 11 Tahun 2008 Tentang Informasi dan Transaksi Elektronik.

Undang-Undang Nomor 16 Tahun 2009 Penetapan Peraturan Pemerintah Pengganti Undang-

Undang Nomor 5 Tahun 2008 Tentang Perubahan Keempat Atas Undang-Undang

Nomor 6 Tahun 1983 Tentang Ketentuan Umum Dan Tata Cara Perpajakan.

Undang-undang Nomor 8 Tahun 1983 tentang Pajak Pertambahan Nilai Barang dan Jasa dan Pajak Penjualan atas Barang Mewah sebagaimana telah beberapa kali diubah terakhir dengan Undang-undang Nomor 18 Tahun 2000 yang tetap dinamakan Undang-undang Pajak Pertambahan Nilai 1984.

Peraturan Pemerintah Nomor 143 Tahun 2000 jo. Peraturan Pemerintah Nomor 24 Tahun 2002 tentang Pelaksanaan Undang-undang Nomor 8 Tahun 1983 tentang Pajak Pertambahan Nilai Barang dan Jasa dan Pajak Penjualan atas Barang Mewah sebagaimana telah beberapa kali diubah terakhir dengan Undang-undang Nomor 18 Tahun 2000.

Peraturan Pemerintah Nomor 144 Tahun 2000 tentang Jenis Barang dan Jasa Yang Tidak Dikenakan Pajak Pertambahan Nilai.

Peraturan Pemerintah Nomor 145 Tahun 2000 tentang Kelompok Barang Kena Pajak yang Tergolong Mewah yang Dikenakan Pajak Penjualan atas Barang Mewah sebagaimana telah beberapa kali diubah terakhir dengan Peraturan Pemerintah Nomor 12 Tahun 2006.

Peraturan Pemerintah Nomor 146 Tahun 2000 tentang Impor dan atau Penyerahan Barang Kena Pajak Tertentu dan atau Penyerahan Jasa Kena Pajak Tertentu yang Dibebaskan dari Pengenaan Pajak Pertambahan Nilai sebagaimana telah beberapa kali diubah terakhir dengan Peraturan Pemerintah Nomor 38 Tahun 2003.

Peraturan Pemerintah Nomor 12 Tahun 2001 tentang Impor dan atau Penyerahan Barang Kena Pajak Tertentu yang Bersifat Strategis yang Dibebaskan dari Pengenaan Pajak Pertambahan Nilai sebagaimana telah beberapa kali diubah terakhir dengan Peraturan Pemerintah Nomor 31 Tahun 2007.

Surat Edaran Nomor SE/62/PJ/2013 tentang Penegasan Ketentuan Perpajakan atas Transaksi 


\section{E-Commerce.}

\section{Sumber Lain}

Agung Budilaksono, Bagaimana Perlakuan Pajak dari Transaksi E-Commerce di Indonesia, http://www.bppk.depkeu.go.id, Widyaiswara Pusdiklat Bea dan Cukai, 2011. Di akses 8 September 2016 11:33

Alvin Toffler, The Third Wave, Toronto New York, London, Sydney: Bantam Books, 1982.

Anwar Nasution, Aspek Ekonomi Anggaran Belanja Negara, Tabloid Prisma Edisi Mei No 5, Jakarta, 1984.

Benno Torgler and Christoph A. Schaltegger, Tax Amnesties in Switzerland and Around the World, Tax Notes International, 2005.

Buyung Muniriyanto, Menelusur Pajak Atas Transaksi E-Commerce, http://www.pajak.go.id/content/article/menelusur-pajak-atas-transaksi-e-commerce, Kamis 23 April 2015, diakses pada tanggal 7 September 2016 - 13:32.

Danny Darussalam, Tax Amnesty Dalam Rangka Rekonsiliasi Nasional, Inside Tax Edisi 26, 2014.

Dini Wahyu Hapsari, Peranan Account Representative Terhadap Kegiatan Intensifikasi Perpajakan Pada Kantor Pelayanan Pajak (KPP). Jurnal Neo-Bis Vol 6 Nomor 1 Juni 2012, Bandung, 2012.

Dwika, "Keadilan dari Dimensi Sistem Hukum", (02/04/2011), http://hukum.kompasiana.com, diakses pada 22 Juli 2016.

E-Commerce di Indonesia Sudah Diatur Dalam UU Perdagangan, Jumat, 17 Oktober 2014 $11: 11$.

Jacques Malherbe, Tax Amnesties in The 2009 Landscape, Bulletin for International Taxation, 2010.

James Alm, Jorge Martinez-Vazquez and Sally Walace, Do Tax Amnesties Work?: The Revenue Effect of Tax Amnesties During the Transition of Russian Federation, Economic Analysis and Policy Vol 39, 2009.

Jay MS, Peran e-Commerce dalam Sektor Ekonomi dan Industri, makalah disampaikan pada seminar sehari aplikasi Internet di era millennium ketiga, Jakarta, 2000.

Kamlesh K. Bajaj dan Nebjani Nag, Electronic Commerce the Cutting of Business, Tata Mc Graw Publishing Company Limited, New Delhi, 2000.

Kenali Aturan Dalam Pelaporan Pajak, Minggu 11 November 2012 13:02, di akses 10 September 2016 22:57.

Lewis Jr. Stephen R, Taxation for Development: Principle and Application, New York: Oxford University Press, 1984.

Milka Casanegra de Jantscher dan Richard M. Bird, Tax Reform of Tax Administration, in the Improving Tax Administration in Developing Countries, Washington D.C.: International Monetary Fund, 1992.

Nufransa Wira Sakti, Kepala Subdit Manajemen Transformasi dalam Seminar Perpajakan "Pemenuhan Kewajiban Perpajakan Bagi Pelaku e-Commerce Di Indonesia" yang diadakan oleh Direkorat Jenderal (Ditjen) Pajak di Jakarta, 27 Agustus 2014. Makalah.

Nur Arianto, "Ekstensifikasi Pajak dari Transaksi Perdagangan Online", http://www.kemenkeu.go.id/sites/default/files/EKSTENSIFIKASI\%20PAJAK\%20 DARI\%20TRANSAKSI\%20ONLINE.pdf, Diakses pada 31 Agustus 2016 12:49. 